\title{
Families, Insanity, and the Psychiatric Institution in Australia and New Zealand, 1860-1914
}

\section{Catharine Coleborne}

\begin{abstract}
International historians have begun to challenge the view that the nineteenth-century psychiatric hospital was a place of horrors and custody, and have shown that families were sometimes intimate with the institutions of the past, often participating in the process of institutional committal. This article explores the state of historical inquiry into families and insanity in Australia and New Zealand. It asserts that by re-examining patient cases we might find fresh insights into the dynamic between families and mental health. Through a close examination of archival sources, the article argues, we can see the presence of families 'inside' the asylum in several ways. Overall, the article suggests that institutional archives present both opportunity and risk for historians intent on discovering 'what happened' to the insane and their families.
\end{abstract}

In our present context, an era of post-deinstitutionalisation, public debate about the relevance and efficacy of now-closed psychiatric institutions has highlighted the roles of families in the process of caring for those with mental illness. Many families in the present struggle with their perceived lack of help, and make use of community and non-government organisations in their efforts to cope with a variety of mental health problems. Their experiences raise questions about mental health care in the past, and in particular, about the role played by families as they related to large, public institutions, many of which were finally closed in the period from the late 1970s through to the 1990 s.

The wider context for these issues has been discussed by historians in recent years. ${ }^{1}$ And over the past two decades historians have begun to challenge the public and commonsensical view that the nineteenth-century psychiatric hospital was a place of horrors and custody, and have shown that families were sometimes intimate with the institutions of the past, often participating in the process of institutional committal. This article explores the state of the field of 
inquiry around families and insanity in Australia and New Zealand, drawing upon a large research project to examine European families and public psychiatric institutions in four colonies between the $1860 \mathrm{~s}$ and $1914 .^{2}$

Here, in order to reflect on the issues raised by contemporary concerns over the pressures placed on families in the present, I want to investigate how families coped in the past. What kinds of exchanges took place between families and institutional personnel? What kind of language was used to describe states of mental disorder, by families and by asylum authorities? What happened to inmates once they were confined, and were their relationships with family members encouraged, or did these fail? I argue that by examining a range of patient cases with an eye on familial relationships and colonial life we might find fresh insights into the dynamic between families and mental health in both the past and the present. Such questions also enable me to continue a discussion about the way historians use the extensive collections of archival materials that relate to institutional confinement in the nineteenth century. While genealogists working in archives have been creating trails to the asylum for many years, locating lost family members inside the patient casebooks, I aim to bring some of these private glimpses of family dynamics into public view.

In order to do this, my research does not confine itself to one locality or institution and presents, instead, a cross-colonial or transTasman site for analysis. Arguably, this type of inquiry, which seeks to escape the boundaries imposed by 'national' histories, enriches our understanding of the variety of familial responses to institutions, and allows us to capture the way that the colonial 'family' as a category was being drawn into asylum management and its discourses of insanity over time. Overall, the article argues that asylum records in their different archival forms, and found in their specific repositories, present both opportunity and risk for historians intent on discovering 'what happened' to the insane and their families.

As many historians have already shown, nineteenth-century records of the psychiatric institution are rich sources of information about families. It was an Australian historian with research experience in Irish archives, Mark Finnane, who in 1985 published a nowseminal article which highlighted the inherent tensions in the field of asylum history after a decade of inquiry influenced by the debates around social control. ${ }^{3}$ Finnane pointed out that a close examination of the way families used institutions would reveal more about the 
complexities of asylum committal, and would explain in part the appeal of institutional confinement to members of nineteenth-century society. It was another Australian historian, Stephen Garton, who took up some of these ideas in his important 1988 work Medicine and Madness, which drew upon patient records in different psychiatric institutions in New South Wales and introduced gender as a category of analysis. ${ }^{4}$ It is now clear that the vigorous debates in social history in the 1980s in Australia and elsewhere helped to shape future generations of students in the field, many of whom were also influenced by the deepening importance of feminist studies in the academy. Still dependent upon archival materials, but also exploring their silences and obfuscations, historians in the field began a new series of inquiries into 'history from below' which has centred on constructions of psychiatric patients.

Debates about both families and insanity and the methodological approaches to institutional archival records drew upon these studies by Finnane and Garton. David Wright's explorations of the history of psychiatry include a robust discussion in 1997 about historians 'getting out of the asylum,' as it were, to discover its history. Citing a range of historical studies around the western world, Wright argued that the context of social change might explain the high volume of traffic in and out of psychiatric institutions in the nineteenth century, as well as shed light on its social role. Wright's own research also exemplifies another strand in the wider field, that of the quantitative approach. Large-scale analysis of data would begin to provide answers to some of these research questions about households and stress in the industrialised world. ${ }^{5}$ More recent work about families and psychiatry takes up new theoretical paradigms to investigate the issue of lay language and clinical diagnosis, such as Akihito Suzuki's work; and the issue of gender and the family, specifically in relation to puerperal insanity, in the work of Hilary Marland. ${ }^{6}$ Numerous studies of the different roles played by families, including those that examine ethnicity and race, all insist upon the more complex meanings of institutional confinement, and bring out an increasingly nuanced reading of the mental hospital in history. ${ }^{7}$ Significant to my own research, Finnane, Garton, and Wright have all suggested that comparative historical studies might prove to be more fruitful than more narrowly conceived studies of single institutions.

Archival materials, in particular, patient case records, family and institutional correspondence, and committal papers, form the basis of this study. My intention has been to explore the array of sources in 
a qualitative study based on a selection of 215 patients that situates individuals and families in their time and place. In each of the four colonies under examination, I chose one large public asylum, usually close to a growing urban centre. These institutions were all operating in the 1860 s and still operating by 1914 . Changes to the psychiatric hospitals following the end of World War I made this a useful point at which to end my study, along with issues around access to patient case material in the twentieth century.

By taking this broad, trans-colonial approach, I can demonstrate that families and individuals actively encountered and used specific institutions: 'Gladesville' in Sydney; the 'Yarra Bend' in Melbourne; Woogaroo or 'Goodna,' located between Brisbane and Ipswich; and 'The Whau' in Auckland, later known as the Auckland Mental Hospital. They knew the way that these places seemed to operate, and they sought medical advice about family members in trouble, or ill with insanity. They sought the assistance of police and magistrates. They also knew, often more obviously by the late 1880 s and the early 1900 s, how to apply to the asylum for access to their sick relative. These institutions were well known in the lives of colonial families, and their status improved over time. ${ }^{8}$ Dr Frederic Norton Manning, who as Inspector-General of the Insane was a prominent figure in the history of mental health in New South Wales, commented in 1879 that it was a 'striking fact' that the new name of 'hospital' was adopted by the patients 'who gladly addressed their letters from Gladesville Hospital.' 9

However, this line of thinking is easily challenged, often, again, by genealogists, who comment that their own family reactions to discoveries of past psychiatric confinement have been far more veiled and circumspect. Families also harbour secrets, and mental illness is often among them. Manning's own public reputation aside, early psychiatric institutions were not always defined by their compassionate and successful superintendents. And families could also be politely rebuffed or confused by asylum processes. In the case of patients who died inside the institution, one imagines that, reading correspondence between families and the institution, the authorities were sometimes simply unable to fully comprehend the grief and puzzlement expressed in family letters. In the present, a poorly explained institutional death would cause uproar; in the past, aside from official inquiries in some colonies, usually prompted by internal institutional scandals, most family concerns remained silent, and were hidden from public attention. 
Therefore, in coming to terms with the agency experienced by families in the past, I do not want to lose sight of the specific relations of power which framed their encounters and sometimes struggles with institutional authorities. ${ }^{10}$ Instead, I intend here to draw attention to the ways that families did in fact find ways to engage with institutions. At the same time, the evidence suggests that historians in the present might not ever know how far families were able to seek and find answers to their important questions about mental breakdown, because historical research takes place within the limitations of official archival collections. This article explores these issues by looking at the key ways in which families appear inside official asylum writing and letters; and at how their stories can illuminate our historical readings of insanity in this context. It also seeks to comment on what kinds of new insights about families in the colonial period can be gleaned through a re-reading of institutional records. The central focus of the article lies in this examination of archival materials and their potential for researchers. I consider several themes which inform this subject before commenting more carefully on the specific issues that surround archival research in this field. But in order to make sense of these materials both in their context, and also within the research I have conducted, I first map out the parameters of the study.

\section{'Scattered about over two colonies': A cross- colonial study}

Many of the patient cases sampled for this research provide evidence of the importance of moving beyond one locality or institution to discover the wider experiences of families in the colonial context. In 1904, writing from the suburb of Brighton, Melbourne, to Eric Sinclair, then medical superintendent of Gladesville Hospital for the Insane, Sydney, one father described his daughter's experience of 'family.' Lissie, as she was known, was 'practically an orphan' from the age of twelve. Her father's view was that she had no relatives of good character. She had been engaged in the 'drudgery of domestic service' and 'yearning for her own home and her own flesh and blood,' but family members were 'scattered about over two colonies.' He concluded that a 'girl of her temperament' felt lonely and bereft of 'home." ${ }^{11}$ The casebook described Lissie as a 'tall, rather anaemic girl.' She was twenty-three years old when she was admitted to the hospital. Born in New South Wales, she had, reportedly, 'no 
home,' and had been a servant until bouts of 'acute mania' led to her committal. Her mother had committed suicide by drowning, her brother was reputedly insane, and her sister was an imbecile. Her father's letter followed her admission, and offered her 'history,' and opinions about what may have led to her illness. ${ }^{12}$

This short story about Lissie's case serves to illustrate some problems which frustrated asylum medical superintendents over time. The meanings attached to 'flesh and blood,' or kinship, were multiple and contested in this context. Lissie's own kin were 'scattered' across the colonies, like so many of the inmates who appear in the case records of different institutions. 'Home' was a place where she might feel safe; but where was 'Home'? And did 'Home' stand in for family, or the lack of family, in the colonial world? Most people did not live out their lives in singular, isolated contexts. Institutional authorities grappled with the difficulty of tracing family members to find out more about people who came to the institutions, sometimes brought by employers, police, and others.

Lissie's case also tells us that we need to look beyond the experiences of families and institutions in one location in this period. The colonial world was not fixed or static; people moved around and between the colonial sites I have examined. This was a complex setting. Historians including Philippa Levine have engaged in crosscolonial studies of disease and empire. Warwick Anderson also draws attention to the potential for medical historians of colonial medicine to become 'nomadic themselves,' 'investigating disease biomedical science and health at a number of sites, tracing the passage of metaphor, practice, money and career between them.' Anderson argues here for histories of colonial medicine to account for the 'mobility of ideas, models, and practices' in order to create 'dynamic, multisited histories of medicine.' 13

Indeed, the exchanges of ideas about psychiatry that took place in the colonial world of Australasia were no less significant than those occupying the minds of Europeans. In addition, a deliberate attempt to define imperial practices around insanity had begun by the 1860s. ${ }^{14}$ Europeans who were establishing new parts of the Empire invented and monitored shifting patterns of population by measuring health and illness. As part of this enterprise, the colonial asylum patient populations were duly counted based on the content of patient casebook records. Patients' mental and physical disorders, alongside their religious denominations, places of origin, occupational categories, and their experiences of committal and discharge, were 
all quantified each year, and the statistics presented to colonial parliaments. Colonial asylum statistics were often compared with each other, and with England, Ireland, Scotland, and Wales. The four public institutions examined in this project were each a part of a wider network or system of asylums in the colonial world, as well as being part of a much broader pattern of asylum management in the Anglo-American world.

As Lissie's story illustrates, and as historians have argued in other contexts, families and patients belong in this discussion about asylum management. Families used asylums in many different ways, as 'quasimedical' institutions, as holding places, and as welfare institutions; and importantly, as argued above, family communications with institutions sometimes, though not always, attest to 'strong affective relations,' with evidence that families were active in the processes of committal and discharge. ${ }^{15}$ The level of detail in the archival materials provides a welcome insight into family and patient agency in the matter of asylum committals. However, Lissie's time at Gladesville (pictured in Image 1) was relatively short: she was discharged in 1906. Her story highlights the major question investigated here: how the archive and its possibilities and limitations inevitably provide a partial account of families and insanity in the colonial world. The remainder of this article explores both the opportunities and risks inherent to archival records of families and insanity through a discussion of themes which underpin the research.

\section{Families inside the asylum}

One of the institution's expressed purposes for existence was to confine individuals to keep them safe, to 'cure' them, and sometimes to relieve relatives of difficult situations in the household, thus separating the insane from the rest of the world. However, the borders between the institution and the outside world were not as distinct as we have sometimes supposed. Authorities often sought help from families, thereby acknowledging a role for families in the matter of treatment and possible cure; and it also, increasingly, sought family perspectives on mental breakdown and the patient's history. So it is possible to see that families appear 'inside' the institution. We can see the presence of families inside the asylum in several ways: first, families 'inside' medical case notes; second, families present in correspondence to and from the institution; and third, the relationships families had with the asylum through visiting, through 


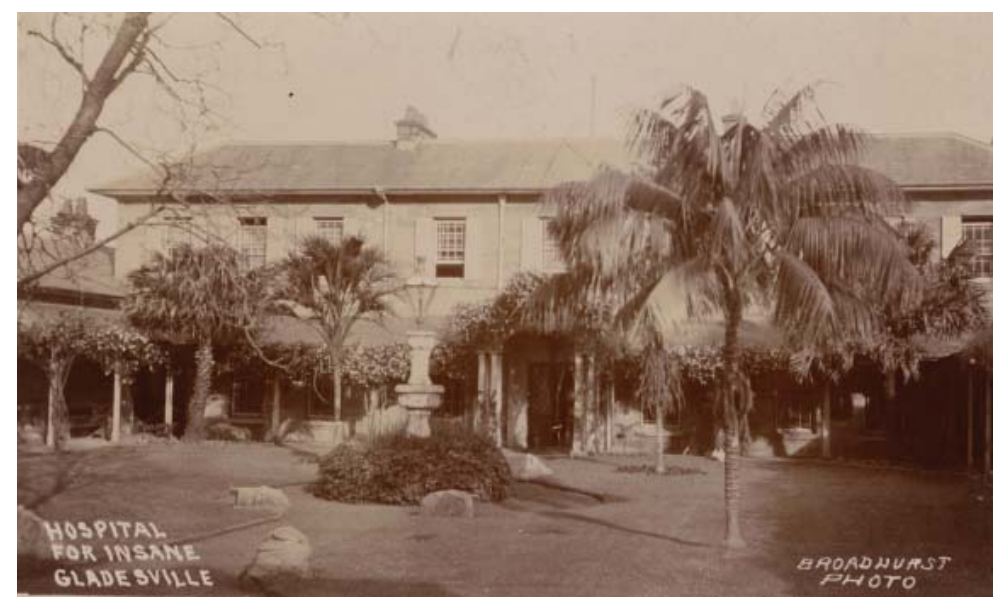

Image 1: Hospital for the Insane, Gladesville, circa 1900. (W.H. Broadhurst Postcard. Reproduced with the permission of the Mitchell Library, State Library of New South Wales, Australia.)

the mechanisms of institutional committal and leave, and through the collection of maintenance payments.

What happens when we begin to examine lay descriptions of insanity, especially the use asylums made of family observations of inmates prior to and at the point of committal? This theme is at the centre of my project, because it allows me to explore the intersections between family and clinical descriptions of mental breakdown. At Auckland, patient casebooks from the 1880s show that a specific section of the notes on the patient was set aside to detail family observations collated from the committal documents, as well as separate notes on the family history. The sister-in-law of May H described her in 1909: 'says patient has always been of a melancholy morbid disposition.' May's brother's comments were set out in the asylum's style, showing he had responded to questions at her committal. May had been born in Auckland, and spent all her life in New Zealand. She was 'originally dull,' had a 'good memory' and a 'strong will,' but was 'placid, not affectionate nor energetic.' She had 'no vices' and 'no cause for grief' but she had been 'absent minded for six months.' Her brother speculated the cause of her illness was 'solitary life. ${ }^{16}$ In Sydney, Gladesville cases gathered similar details from family members, employers, and friends. However, unlike Auckland cases, these were transferred from separate committal papers and copied into patient case files as marginal notes, some 
more substantial than others.

The content of cases reflected the type of observations made by those seeking medical advice about committal. In addition, these family observations sometimes also reflected the social context of committal, as historians have shown. Women, it was sometimes noted on committal, neglected their household duties; men were often threatening towards wives and children. ${ }^{17} \mathrm{John}$ A's wife described his behaviour in 1904: 'he suddenly jumps out of bed in the night and runs round the house in search of imaginary enemies armed with an axe or crowbar and says he will make a clean sweep of the whole of them if they do not let him alone.' She also said that he laughed 'immoderately' for half an hour at a time for no reason. ${ }^{18}$ Maori patients were often brought to the Auckland asylum only after contact with Europeans, and were more likely to have been physically unwell, and suffering from the shock of cultural contact with whites in an institutional setting. ${ }^{19}$ Many others without family were observed in public or by their neighbours or employers.

The gathering of family data suggests two things. First, institutions needed to reply upon accounts of mental breakdown offered by those close to patients because patients themselves were often 'incoherent' at the time of admission. Records show that where possible, patients were 'interviewed' about their own states of mind, although this practice was haphazard and not routine; the same records may be read for evidence of the patient's own 'voice.' Second, institutions were increasingly concerned to uncover patterns in instances of family insanity so that the data about heredity could be explained; this became more critical with the rise of discourses around mental hygiene in the latter part of the nineteenth century.

The asylum incorporated these observations by family members in casenotes and later, official statistics (for instance, in tabulations of the different causes of mental breakdown). Thus, lay language made sense of what seemed to be insane behaviour, and families themselves invented ways of describing what they identified as 'strange. ${ }^{20}$ Yet the overall effect of the information supplied by families is one of unevenness and gappiness, as if the struggle to define mental breakdown itself broke down under the pressure of its collection. Casenotes, too, as historians have suggested before now, inevitably represent the sometimes haphazard nature of patient inspection and the recording of medical observations. The loose ends in many patient cases provide historians with many points of frustration, but also, opportunity to speculate; by linking records within archival 
collections much more can be gained from the perceived flaws of casenotes themselves.

Families also made their way inside the asylum in letters and other fragments of their communications with the authorities. These interactions tell us a great deal about how families used the institution, sometimes well known to a family with more than one experience of it. Robert R wrote to the asylum in 1879, specifically to Dr Manning, to seek help for his brother John. He explained that he had assisted his brother financially through difficult times, but that recently his brother had become violent, threatening Robert's wife, and that he had begun talking strangely-he claimed to be 'King of Queensland.' Robert explained that he himself had recently spent time in Gladesville, and that insanity ran in the family. He wrote: 'I shall never be able to repay you for your kindness to me I am only sorry that I did not come before ... I thank God that I have a sound mind and my suffering is not so much. ${ }^{21}$ Letters like this one show that for many families the asylum was a place that might offer a solution to the problem of insanity.

Patients also wrote letters to family and friends outside the institution. Although these letters were not always sent, following institutional practices, it is clear that their contents were frequently communicated to family members and used in the processes of discharge and patient appraisal. Sometimes patients were able to convince asylum authorities of their fitness for discharge, as the following example shows. Christian F, a nineteen-year-old woman from Maryborough in Queensland was admitted to Goodna, pictured in Image 2, in November of 1907, and discharged in February 1908. She wrote to her mother from Goodna that she was 'glad' to be able to report that she was 'well': 'you'll get a surprise when you see me I am not the half-dead sort like I was there. I have got strong and my memory has come back to me.' She expressed her desire to come home, and to take good care of her health once released, and she signed the letter 'your loving daughter.'22

Letters like this also communicate the emotional worlds of patients and their families. Emotional responses to asylum confinement are rarely investigated by historians, but should be considered alongside the mechanics of committal and discharge. Emotions were also framed by the social, cultural, and political contexts of their appearance, with class and gender roles shaping their very expression. For instance, Marland has argued that the experience of motherhood in the Victoria era in Britain could intensify emotions in sometimes violent or deeply 


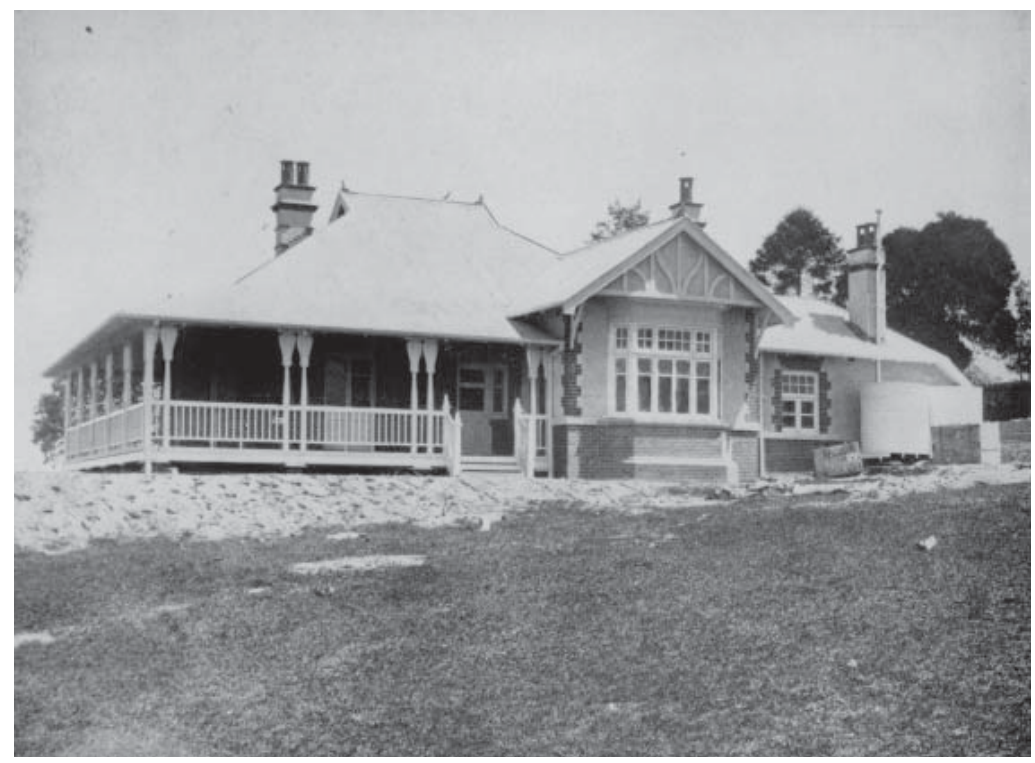

Image 2: Superintendent's residence, Goodna. (Reproduced courtesy of the State Library of Queensland, image no. 177592.)

affecting ways. Women could 'fall prey' to the mental disorders which stemmed from highly emotional periods of pregnancy, birth, and lactation..$^{23}$

In a very few instances - at least of those it is possible to locate-families make their way inside the asylum walls in person. It is not always easy to find out how often patients were visited by family members, or how those visits were received. John Currie's diary entries have shown that hospital staff sometimes discouraged visitors: at Yarra Bend, when he hoped to see his wife, 'they gave [him] the hint to go away. ${ }^{24}$ But patient cases and letters show that family members often physically encountered institutions at the point of committal, and also at the point of discharge, both highly emotional moments in patients' lives.

The Visitors' Book at Auckland tells us more about the presence of family and friends in the institution. Hundreds of visits were made to patients at Auckland over the period 1891-1911 (see Image 3). ${ }^{25}$ When visitors signed in, they were obliged to note their name and address, the name of the patient being visited and their relationship to that person. Some patients were visited regularly by the same person, others by different family members. In a number of cases, 
both parents of a patient visited together, perhaps providing support during the visit and over the distance travelled. Small family groups also arrived in parties. Some addresses indicate that visitors came from distances of over one hundred miles, including the far north of the North Island. There were also visitors from other colonies, such as the friend of Alfred T, who came from Melbourne to see him in $1902 .{ }^{26}$ By investigating institutional visiting, historians can open up the doors of the asylum for further scrutiny, as I argue elsewhere. ${ }^{27}$ Historians have found that authorities did not always welcome visitors to patients, and sometimes viewed these as disruptive of the institution's management of mental disorder. ${ }^{28}$ As an alternative however, institutions allowed patients to go outside of the asylum for visits, albeit under conditions of supervision. Where the evidence exists, such visits can show the range of relationships experienced by patients and families, both with each other, and with the institutions themselves.

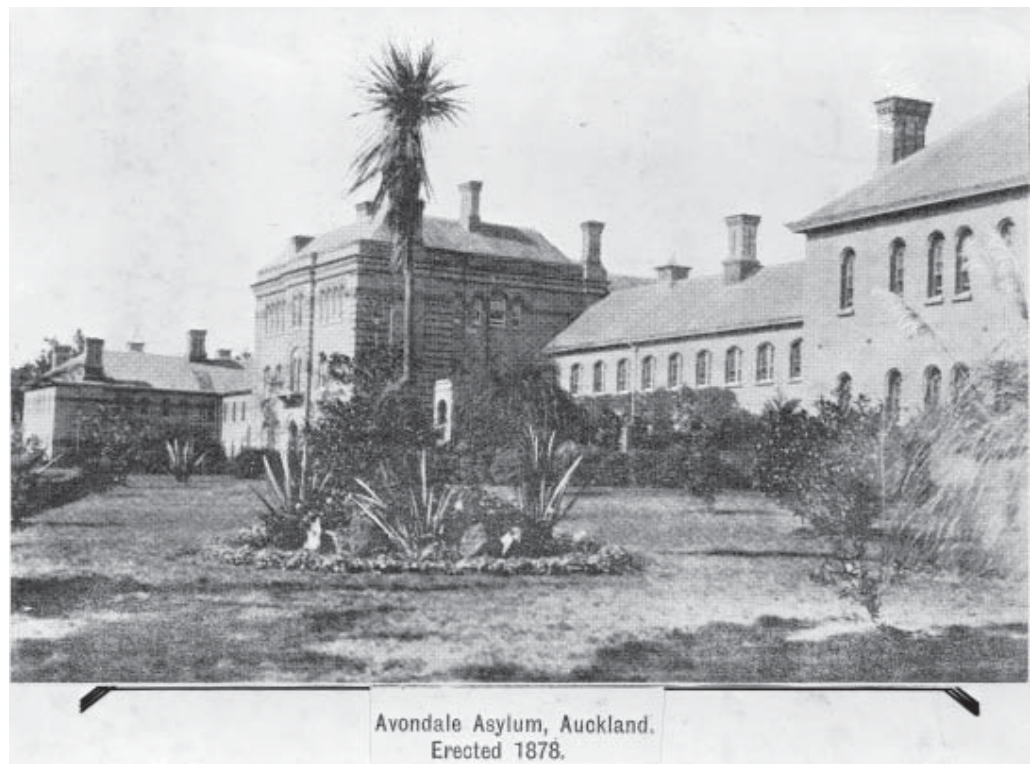

Image 3: Avondale Asylum, Auckland, erected 1878; photo circa early 1900s. (Reproduced with the permission of the Alexander Turnbull Library, Wellington, New Zealand.) 
Practices of allowing patients out on trial leave or leave of absence show that institutions were regularly petitioned by family members. At the Yarra Bend, a register of applications for patients' leave of absence made by family and friends reveals that while caution was exercised, institutional authorities did hope for 'cures' beyond the hospital. Victoria was one colony where the concept of 'boardingout,' made famous in Scotland and some European countries, was seriously entertained for a short period in the late nineteenth century. ${ }^{29}$ In 1899, Margaret K's mother Honora made a formal request for her daughter to leave the asylum at Yarra Bend, stating 'I am desirous of removing the patient ... although Dr Watkins informs me that she will require special observation for some time; and I agree to provide such attention.' ${ }^{30}$ Margaret had been admitted two years earlier suffering from delusional melancholia; she was a farmer's widow who cared for her five young children. The request was approved, and later that year Margaret was finally discharged. Others made similar undertakings, often writing to the institution to explain their circumstances, in the hope that the Inspector of Lunatic Asylums would look kindly on their plight.

Periods of leave could be granted to patients who may have seemed at risk once released on trial. The reasons for leave were complex and often related to family roles and responsibilities. When, in 1894, Frances K claimed to have 'sold herself to the devil,' she was taken to Gladesville where she stayed for around a year. Pronounced a 'melancholic,' she set about writing to her Aunt Annie. 'Will you come and see me,' she asked, 'now the month is up I want to know about my children.' She was worried she had neglected them: 'I do not know one moment's peace my life is a living death.' Sometime later, she was granted a leave -of absence from the institution before her eventual discharge in $1895 .{ }^{31}$

Maintenance payments and their collection also shed light on familial relationships and attitudes towards asylum confinement. The problem of maintenance payments also highlights one aspect of the colonial mental hospital that differs concretely from similar hospitals in parts of Britain and America, where the pauper and private institutions were distinct. ${ }^{32}$ Yet the patchy records of payments made by families to the different institutions in this study reveal that despite official anxiety about the low returns, and institutions' own attempts to retrieve monies owed, many families were simply unable to meet payments over longer periods of time. Once again, the different practices of maintenance collection and record keeping across the colonies are reflected in the archival sources. For instance, 
at Auckland, the Record Book of Maintenance Investigations 1885-9, which is a companion to the Maintenance Payment Ledger, provides extensive detail about some families and patients, while both the schedule of maintenance bonds at the Yarra Bend, and records of the collection of payments at Gladesville, are less descriptive.

\section{Grappling with archival records: Some conclusions}

Historians have shown that finding out about the lives of asylum inmates and their families has been difficult, but not impossible. Despite the frustrating unevenness of archival records, extant records do indicate that colonial societies were engaged in different ways with how to protect and care for people whose minds and lives had become crowded with the sometimes delusional thinking produced by their psychiatric conditions. At the same time, as Emma Spooner has shown, institutional and archival practices can obscure these histories: what we can ever 'know' about mental breakdown in the past is contingent upon the way the archival sources have been collated, what is extant, and how we read these materials. ${ }^{33}$

To find out about these problems, historians are working with the same fragmentary evidence we have always had, but are interpreting it in new ways. We need to explore the ways in which evidence emanating from the institutions shows us that families were in fact present at committal, discharge, and during patients' stays in the institution. However, the quest to discover 'agency' within official records, or how families defined their roles in relation to the institution, is not the only aspect of a re-reading of asylum source materials. The different archives utilised in this study each also represent and produce 'the family' in distinct ways, and reveal the potential of trans-colonial studies. Navigating the different archival systems used in each colony, later state archives or Public Records offices, and, in New Zealand's case, National Archives, has involved a very useful scrutiny of hospital record-keeping practices, and, in essence, attitudes held by the chosen public institutions towards 'the family' itself.

For example, the impact of the shaping of Gladesville cases, with marginal notes forming part of the clinical record, provides an interesting point of comparison with the notes collected at Auckland. In the Gladesville cases, the family seeps into asylum practices and becomes part of the clinical observation, both intruding into it and also occupying a role in it, performing what historians have described as a dialogue between families, patients, and institutional 
authorities. ${ }^{34}$ Letters are sometimes separated from patient cases in archival collections, such as those for Gladesville. Others are stored inside patient casebooks but protected from deterioration by clear plastic, such as those in the Queensland records of Goodna Hospital. In both places, these archival interventions manage to create the effect of a hidden and incomplete world of communications beyond the researcher's grasp. Such 'fleeting registers in the colonial record,' as Tracey Banivanua-Mar has argued in a different context, hint at stories 'with no ending or conclusion., 35

Archival materials should be re-examined as rich sources of information about families, households, and most importantly, the language used by ordinary people to describe mental states. The traces of emotion found in patient case histories are a moving, disturbing, and yet inconsistent set of reminders of the calamity of insanity. Letters to and from family members of the insane, patients themselves, and medical authorities offer the possibility of a deeper reading of the emotions surrounding psychiatric confinement. We can also explore the porous boundaries of the asylum through the themes of leave of absence, readmission, and maintenance payments, and discover that families had many and multiple interactions with colonial institutions in this period. ${ }^{36}$ Debates across the period about methods of extra-institutional care, including boarding-out and trial leave, show that the institution's walls were not impermeable. How did families and communities cope with insanity back inside the space of the private household? How did patients themselves cope with this transition? And finally, the outcomes for patients who were able to navigate the spaces between the asylum and the community, including discharge, are an important reminder, in our present, of the institution's past function and meanings.

\section{University of Waikato}

\section{Acknowledgments}

Sincere thanks to Professor Mark Finnane, and others at Griffith University, for organizing the event at the Museum of Brisbane in November 2007 where these ideas were presented to a public audience in a different form. Thanks to two anonymous referees for their very useful critique. I acknowledge the assistance of archivists at State Records New South Wales, Western Sydney; Queensland State Archives, Brisbane; the Victorian Public Record Office, Melbourne; and the National Archives, New Zealand, Auckland Branch. State Records New South Wales has granted permission for their archival materials to be quoted in publications arising from my research in accordance with their rules. This research has been funded by the Royal Society of New Zealand's Marsden Fund. 
1. See, for instance, Health \& History, Special Issue: Histories of Psychiatry after Deinstitutionalisation: Australia and New Zealand 5, no. 2 (2003): 1-149.

2. Research for this project was funded by the Marsden Fund (Royal Society, New Zealand, 2004-06). It will appear as 'Madness' in the Family: Insanity, Institutions and the Australasian Colonial World, 1860s-1914 (Palgrave, forthcoming). This article ranges over the different themes in the book, rather than taking a separate chapter as a focus, to avoid duplication in published works. Although some indigenous patients and families appear in areas of my research, particularly in the New Zealand context, the majority of families in my study were drawn from European groups. I try to be historically accurate in my use of terms that were current during the period of my study, but I note that they sometimes sound unusual and even offensive to many readers, such as 'asylum' or 'imbecile'; other terms are used with an awareness of how problematic they may be: 'insane,' 'insanity,' 'mental breakdown,' 'patient.' Names of institutions change over time, but I have used the names that were current and mostly consistent during the period that I am investigating. Ethical permission has been granted to perform this research. I remove surnames of institutionalised persons at all times, and I also endeavour to research and write in an ethical manner about these sensitive issues, including where they impinge on the histories of Māori and Aboriginal pasts.

3. Mark Finnane, "Asylums, Families and the State," History Workshop 20 (1985): 134 48.

4. Stephen Garton, Medicine and Madness: A Social History of Insanity in New South Wales, 1880-1940 (Kensington, NSW: New South Wales University Press, 1988).

5. David Wright, "Getting Out of the Asylum: Understanding the Confinement of the Insane in the Nineteenth Century," Social History of Medicine 10, no. 1 (1997): 137-55.

6. Akihito Suzuki, "Framing Psychiatric Subjectivity: Doctor, Patient and Record-keeping at Bethlem in the Nineteenth Century," in Insanity, Institutions and Society: A Social History of Madness in Comparative Perspective, edited by Joseph Melling and Bill Forsythe (London and New York: Routledge, 1999); and Hilary Marland, Dangerous Motherhood: Insanity and Childbirth in Victorian Britain (Houndmills, Basingstoke, Hampshire and London: Palgrave Macmillan, 2004).

7. See Mary-Ellen Kelm, "Women, Families and the Provincial Hospital for the Insane, British Columbia, 1905-1915," Journal of Family History 19, no. 2 (1994): 177-93; Patricia Prestwich, "Female Alcoholism in Paris, 1870-1920: The Response of Psychiatrists and of Families," History of Psychiatry 14, no. 3 (2003): 321-36; and Marjorie Levine-Clark, "Dysfunctional Domesticity: Female Insanity and Family Relationships among the West Riding Poor in the Mid-Nineteenth Century," Journal of Family History 25, no. 3 (2000): 341-61.

8. Finnane, "Asylums, Families and the State."

9. Frederic Norton Manning, "Address delivered on resigning charge as Medical Superintendent of the Hospitals for the Insane at Gladesville and Callan Park" (1879, Sydney), D.I. MacDonald papers, National Library of Australia, MS 5147.

10. Indeed, my own work has emphasised this theme of power to a large extent; see Catharine Coleborne, Reading "Madness": Gender and Difference in the Colonial Asylum in Victoria, Australia, 1848-1880s (Perth, Western Australia API Network, Curtin University Australia Research Centre, 2007).

11. State Records NSW (hereafter SRNSW), Gladesville Hospital, CGS 5034, Letters concerning patients, 4/8207, Letter 110 .

12. SRNSW, Gladesville Hospital, CGS 5031, 1857-1925, Medical casebooks, Folio 56. This patient was named Marion but known as 'Lissie' in her father's letter.

13. See Phillipa Levine, Prostitution, Race and Politics: Policing Venereal Disease in the British Empire (London and New York: Routledge, 2003); Warwick Anderson, "Postcolonial Histories of Medicine," in Locating Medical History: The Stories and Their Meanings, edited by Frank Huisman and John Harley Warner (Baltimore and London: Johns Hopkins University Press, 2004), 299-300.

14. See, for example, the report tabled to colonial parliaments in 1864: Hospitals and Lunatic Asylums, Victoria Parliamentary Papers (hereafter VPP) 1864-65, vol 3, which was a review of colonial institutions commissioned in England.

15. James Moran, David Wright, and Matt Savelli, “The Lunatic Fringe: Families, Madness, 
and Institutional Confinement in Victorian Ontario," in Mapping the Margins: The Family and Social Discipline in Canada, 1700-1975, edited by Nancy and Michael Gavreau Christie (Montreal and Kingston, Canada; London; Ithaca: McGill-Queen's University Press, 2004), 296-7. However, Stephen Garton also argues that institutional records show that families were highly fractured and that they often did not exhibit strong relationships or close family ties. This is also a feature of my study; see Garton, 189.

16. National Archives, Auckland Branch, YCAA Carrington Hospital, 1048/11, folio 95.

17. Garton, Medicine and Madness; Bronwyn Labrum, "Looking Beyond the Asylum: Gender and the Process of Committal in Auckland, 1870-1910," New Zealand Journal of History 26 (1992): 125-44; and "The Boundaries of Femininity: Madness and Gender in New Zealand, 1870-1910," in Women, Madness and the Law: A Feminist Reader, edited by Wendy Chan, Dorothy E Chun, and Robert Menzies (London; Sydney; Portland, Oregon: Glasshouse Press, 2005).

18. SRNSW, Gladesville Hospital, 4/8191, folio 226.

19. Lorelle Burke, “'The Voices Caused Him to Become Porangi': Maori Patients in the Auckland Lunatic Asylum, 1860-1900," (unpublished Masters Thesis in History, University of Waikato, 2006).

20. See work in this area by James Moran, "The Signal and the Noise: The Historical Epidemiology of Insanity in Ante-Bellum New Jersey," History of Psychiatry 14, no. 3 (2003): 281-301. See also my arguments made in more detail in Catharine Coleborne, "'His Brain was Wrong, his Mind Astray': Families and the Language of Insanity in New South Wales, Queensland and New Zealand, 1880s-1910," Journal of Family History 31, no. 1 (2006): 4565.

21. SRNSW, Gladesville Hospital, 4/8175, folio 69.

22. Queensland State Archives (hereafter QSA), Wolston Park Hospital (formerly Goodna), A/45649, 11 November 1907, folio 49.

23. Hilary Marland, "Language and Landscapes of Emotion: Motherhood and Puerperal Insanity in the Nineteenth Century," in Medicine, Emotion and Disease, 1700 -1950, edited by Fay Bound Alberti (Houndmills, Basingstoke, and New York: Palgrave Macmillan, 2006), 53-5. See also Catharine Coleborne, "Families, Patients and Emotions: Asylums for the Insane in Colonial Australia and New Zealand, 1880s-1910," Social History of Medicine 19, no 3 (December 2006): 425-42.

24. Ann Catherine Currie, Farm Diaries 1873-1916, La Trobe Australian Manuscripts Collection, State Library of Victoria, MS 11106.

25. This Visitors' Book is not paginated, but could easily contain a record of 20 visits per page, in a book of around 200 pages or more, over this time period. It is only a fraction of information about visiting which most likely occurred throughout the nineteenth century in a similar pattern.

26. Public Record Office Victoria (hereafter PROV), Yarra Bend Lunatic Aslym YCAA 1075/1, Visitors' Book 1891-1911, 23 June 1902.

27. On asylum visiting, see for instance Jospeh Melling and Bill Forsythe, The Politics of Madness: the State, Insanity and Society in England, 1845-1914 (London and New York: Routledge, 2006), 100; see also Catharine Coleborne, "Challenging Institutional Hegemony: Family Visitors to Hospitals for the Insane in Australia and New Zealand, 1880s-1900s" in Permeable Walls: Historical Perspectives on Hospital and Asylum Visiting (Clio Medica/The Wellcome Series in the History of Medicine), edited by Graham Mooney and Jonathan Reinharz (London: Wellcome Institute and Rodopi, forthcoming).

28. For example, Mary-Ellen Kelm, "Women, Families and the Provincial Hospital for the Insane, British Columbia, 1905-1915," Journal of Family History 19, no 2 (1994): 180-3.

29. On boarding-out, see Harriet Sturdy and William Parry-Jones, "Boarding-out Insane Patients: the Significance of the Scottish System 1857-1913," in Outside the Walls of the Asylum: The History of Care in the Community 1750-2000, edited by Peter Bartlett and David Wright (London and New Brunswick, NJ: The Athlone Press, 1999), 110-11.

30. VPRS 7570/P1, I, F99/1770, Bundle 1; VPRS 7400 P0001, Unit 12, Folio 83, 23 December 1897.

31. SRNSW, Gladesville Hospital, 4/8182, folio 238; CGS 5035, Letters from patients, 4/8203, no 228, January 1895 . 


\section{CATHARINE COLEBORNE}

32. However, some patients admitted to public asylums in England were pursued for maintenance payments; see Joseph Melling and Bill Forsythe, The Politics of Madness: The State, Insanity and Society in England, 1845-1914 (London and New York: Routledge, 2006), 173, 194, 221 n 24.

33. For an extended argument about the asylum archive, see Emma C. Spooner, "The Mind is Thoroughly Unhinged': Reading the Auckland Asylum Archive, New Zealand, 1900-1910," Health and History 7, no 2 (2005): 56-79. Spooner's Masters Thesis, which formed part of the Marsden-funded project described here, examined the appearances and constructions of families in the Auckland Asylum records between 1870 and 1911. This work provides a more detailed account of families and the archive than I can provide here; see Emma Catherine Spooner, "Digging for the Families of the Mad: Locating the Family in the Auckland Asylum Archives 1870-1911" (Unpublished Masters Thesis in History, University of Waikato, 2006).

34. Charles E. Rosenberg and Janet Golden, eds, Framing Disease: Studies in Cultural History, (New Brunswick and New Jersey: Rutgers University Press, 1992), xvi; Nancy Theriot, "Women's Voices in Nineteenth-Century Medical Discourse: A Step toward Deconstructing Science," Signs 19, no. 1 (1993): 1-31.

35. Tracey Banivanua-Mar, Violence and Colonial Dialogue: The Australian-Pacific Indentured Labor Trade (University of Hawai'i Press, Honolulu, 2007), 149.

36. Some research has been conducted about families, violence, discharge, and readmission in New Zealand in the period as part of the wider research project described here; see Jennifer Robertson, “'Unsettled, Excited and Quarrelsome': The Intersection of Violence, Families and Lunacy at the Auckland Asylum, 1890-1910" (Unpublished Masters Thesis in History, University of Waikato, 2006.) 